\title{
Ecotourism Policy in India: Rhetoric and Reality
}

\section{G. Poyyamoli}

Department of Ecology \& Environmental Sciences, Pondicherry University, Pondicherry - 605014 India

E-mail: gpoyya@yahoo.com

How to cite this paper: Poyyamoli, G. (2018). Ecotourism Policy in India: Rhetoric and Reality. Grassroots Journal of Natural Resources, 1(1): 46-61. Doi:

https://doi.org/10.33002/nr2581.6853.01015

Received: 28 July 2018

Reviewed: 31 July 2018

Provisionally Accepted: 02 August 2018

Revised: 07 August 2018

Finally Accepted: 10 August 2018

Published: 13 August 2018

Copyright $(2018$ by author(s) and

The Grassroots Institute.

This work is licensed under the Creative Commons Attribution International License (CC BY 4.0).

http://creativecommons.org/licenses/by/4.0/
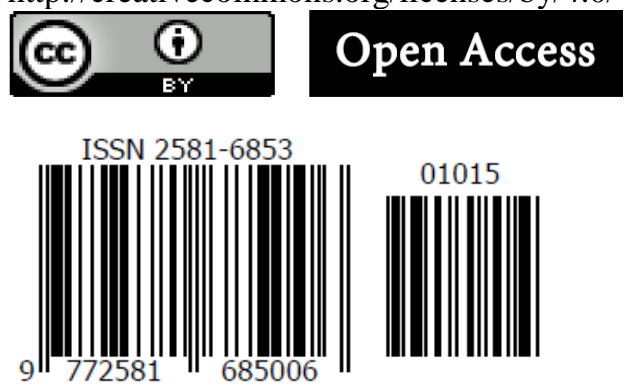

\begin{abstract}
Although there is a National Ecotourism Policy for India, it has serious flaws that permit "green washing" resulting in the degradation of nature and culture in highly sensitive ecotourism destination areas. National Ecotourism Policy is critically reviewed in this article, indicating the lacuna and shortcomings that throw some light on the gap between rhetoric and reality. Remedial policy interventions for promoting authentic ecotourism in India are suggested in this article based on best practice case studies from Asia that will ensure sustainable management of precious natural and cultural resources through community cooperation and collective action at the local and regional level.
\end{abstract}

\section{Keywords}

Ecotourism; Green Washing; Mass Tourism; Sustainability; Livelihoods 


\section{Introduction}

The mass tourism or "conventional tourism" mainly promoted by big conglomerates in the form of several tourist resorts or star hotels and big hotel chains in India monotonously provide the same type of services and facilities everywhere and with little interaction with the local communities. It often degrades the environmental quality, natural/cultural resources, and heritage. In all their operations, environment (e.g. climate, water and sand) and the biocultural diversity - the travel industry's base products - are rarely respected, understood or taken care of. While outstanding/unique natural beauty, cultural landscapes and heritage are competitively advantageous for several destinations, very few in the tourism industry really worry about dwindling number of biota or the damage impinged on the heritage monuments. None cares about acculturation or alienation of tribes and other native communities due to narrow or shortterm profit maximization by tourism industry. Though many of these decisions are irreversible/irrevocable, several players in the tourism industry do not pay adequate attention on these neglected dimensions. Even if they want to remedy the situation, the "tragedy of the commons" prevents them (E.G. Healy, RG1994; Mooreand Rodger, 2010).

Due to such reasons, the conventional mass tourism model is gradually being questioned around the world, and local communities (if not yet governments) have begun to oppose it precisely due to its adverse impacts on biocultural, landscape and infrastructural elements. Large scale public protests against unregulated mass tourism have been witnessed in Barcelona, Venice, Thailand, Nepal and Bhutan (which resulted into imposition of cap on the number of tourists). Given the escalating numbers of tourists in popular tourist destinations in India, the old laissez faire approach will no longer be sufficient. The telltale symptoms are already visible in several destinations in India: worse condition of landscapes in Shimla, Manali and Dharamshala; the traffic jams on Rohtang pass; the desecration of Khajjiar and Triund lakes; the mounds of plastic on the railway tracks between Kalka and Solan; the road in Kufri ankle deep in horse dung; 67,000 pilgrims defecating all the way to Manimahesh lake; the regular hours-long traffic jams on all major highways. The only answer is to build or widen highways in sensitive locations. The Parwanoo-Shimla and Kiratpur-Manali National Highways are prime examples of this myopic vision: all they will do is increased traffic exponentially and destabilize the pristine hills for the next 20 years. The situation is not much different in other tourist destinations of other states, such as Goa.

If planning of tourism and its subsequent implementation are not based on sound ecological and socio-economic principles, there would be several negative impacts, most of them irreversible. Such impacts can be broadly classified into:

- Socioeconomic impacts - chiefly alienation, un/under-employment;

- Cultural impacts - commodification and standardization leading to acculturation; and

- Environmental impacts - chiefly deforestation, soil erosion, overexploitation of natural resources/biodiversity, pollution, etc.

\footnotetext{
${ }^{1}$ The Tragedy of the Commons is an economic theory that describes how people often use natural resources freely available to them for their narrow selfish advantage on a short-term basis without considering the long-term benefits that can be accrued to a group or community as a whole. When a number of individuals consider only their own welfare in this manner, it leads to negative outcomes for everybody (including themselves) as the natural resource becomes depleted and degraded (adopted from https://www.learning-theories.com/the-tragedy-of-thecommons.html). Tourism landscapes (both natural and human modified) possess the characteristics of typical common pool resources - inability to control overexploitation/pollution and lack of incentive for investment that can sustainably manage such commons. For more insights on commons, visit https://www.iasc-commons.org/
}

G. Poyyamoli 
Nature-based tourism concentrated around protected areas has witnessed a growth of $6 \%$ in the last decade in India, as the country is endowed with rich biodiversity (Mittermeier and Mittermeier, 1997; Mittermeier et al., 2011; India Environment Portal, 2011; Vattakaven et al., 2016; Karanth, Jain and Mariam, 2017). Despite the remarkable growth of nature-based tourism in India, the current unregulated mass tourism and pseudo ecotourism approach has had limited benefits to conserve protected areas and local communities (Banerjee, 2010; Karanth and DeFries, 2011; Puri , Karanth and Thapa, 2018).

With successful models in countries of Latin America, Africa and Asia rooted in responsible tourism or ecotourism that can substantially contribute to economies, multiple reasons exist as to why ecotourism could not be established successfully in India. Several workers attributed this miserable failure to the limited scientific and management focus and policy/governance failure on developing community-based or community-run ecotourism as a viable approach (Poyyamoli, 2007, 2008 and 2011; Puri, Karanth and Thapa, 2018). Authentic ecotourism destinations are benefited in the form of enhanced tourism competitiveness from the protection/regeneration of quality natural/cultural resources in all their diverse forms. Such resources are the building blocks of the global ecotourism industry from which a major fraction of the economic benefits is ploughed back into the community in addition to the more valuable ecological benefits. Against this backdrop, this paper provides a road map for revising the national ecotourism policy in India.

\section{Ecotourism: What is and what it is not?}

Ecotourism evolved 'within the womb of the environment movement in the 1970s and 1980s. Increasing concern on environmental, socio-economic and cultural impacts coupled with an emerging dissatisfaction with the largely irreversible impacts of ill-conceived/planned/ implemented mass tourism have led to increased demand for more authentic natural/cultural heritage based experiences of an alternative nature. By mid-1980s, ecotourism was identified as a means of achieving the twin goals of conserving biocultural diversity/heritage and achieving sustainable development in a number of countries.

The concept of sustainable tourism is often confused with ecotourism and people consider them as synonyms. Sustainable tourism is defined as "tourism that meets the needs of the present tourists and host regions while protecting and enhancing opportunity for the future". Thus, it is an umbrella concept that would include the ecotourism. Ecotourism activities are offered by a large and wide diversity of operators and practiced by an even larger array of tourists. While there is no single universal definition for ecotourism, its general characteristics can be summarized as follows:

- All nature-based forms of tourism in which the main motivation of the tourists is the observation and appreciation for admiring, enjoying and/or studying nature as well as the traditional cultural heritage prevailing in relatively undisturbed or uncontaminated natural/cultural areas;

- It is generally, but not exclusively, organized for environmentally/socially conscious small groups of tourists by specialized, and small, locally owned businesses/enterprises, or, at times, by outsiders, but with more local partnerships;

- It reduces negative impacts upon the natural and socio-cultural environment and heritage (both tangible and intangible);

- It promotes the protection of natural areas and the restoration/revival of heritage/culture by generating equitable economic benefits for host communities (by providing a diverse array 
of alternative sustainable employment, income opportunities and economic incentives for conservation);

- It integrates conservation and sustainable livelihoods by active community participation in planning, implementing and monitoring of ecotourism activities in a transparent way to define and regulate the space/resource use at the local level, including the right to opt out of tourism development, as and when needed; and

- It increases awareness towards the conservation of heritage, natural and cultural assets, both among locals and tourists by participatory, interactive, interpretative, enlightening and educational experiences.

\section{Ecotourism: The potentials}

Ecotourism is a large and rapidly growing industry, accounting for US\$ 2 billion globally in 1996. For example, in a national park of Ontario, bird watchers, during peak season of birding season, spent \$ 3.8 million within 24 days in a month, out of which 2.1 million was spent locally. In Southeast Asian countries, ecotourism is increasingly being made a flagship project to attract hard currency for economic recovery and to help communities ride out of the debt crisis.

Though the tourist volume is small, ecotourism can generate sufficient revenue, especially from foreign tourists. For instance, data of 1993 shows that Madagascar earned \$ 275 to 360 per trip to see lemurs; Belize earned \$ 350 per trip for coral reef diving; ACAP Nepal generated additional fees of Rs. 121 per person (80,000 trekkers/year generated Rs. 97,00,000 per year). Interestingly, most ecotourists are from North America and Europe, while most ecotourism destinations are in developing countries. Such destinations have areas of great natural beauty, but are worst hit by poverty, inadequate local participation and unregulated tourism growth. For instance, South Africa has witnessed a $108 \%$ growth rate in ecotourism.

Many of the relatively undisturbed and biologically/culturally restored/conserved richest areas are in the developing world, offering themselves as ecotourism destinations. Tourism here has been increasing annually by $6 \%$ as compared to $3.5 \%$ in developed countries. Ecotourism is increasing by $20-34 \%$ per annum globally, or some six times the growth rate of standard tourism (Herbig and O’Hara, 1997).

\section{Ecotourism: The potential negative impacts of "green washing"}

If ecotourism is not managed properly, large number of ecotourists will trigger pseudo ecotourism. The resultant impacts will be not much different from that of conventional mass tourism. Perhaps they can be even worse. Since the destinations are located in ecologically/culturally sensitive areas, the anticipated impacts would be more severe and often irreversible (Weaver, 2001). Across India, pseudo ecotourism has culminated in more forest/farm land and coastal destruction. Indigenous people in affected areas have been forced out of their traditional lands in some cases, causing economic dislocation, breakdown of traditional values, exploitation of ethno-botanical knowledge base (without any compensation/remuneration) and environmental degradation. Under these circumstances, local communities will continue to be mere cogs in the wheel of this billion dollar industry, if no corrective steps are taken.

Lessons learnt over recent years have confirmed that opening up pristine areas with rich biodiversity and cultural heritage for so-called "top down" tourism-cum-conservation projects 
without any regulations add only to the multi-dimensional impacts of mass tourism. In spite of tremendous opportunities, ecotourism, as it is conceived and implemented in India, has limited potential. It cannot replace mass tourism, and cannot be universally promoted everywhere due to several bottlenecks/shortcomings in the policy. The following would be the most important constraints if ecotourism is not planned/implemented with adequate care:

- Alienation of local traditional communities with negative effects on their livelihood security;

- Inducement of faster acculturation endangering the valuable traditional knowledge base; and

- Creation of negative images about wildlife while encouraging poaching and overexploitation.

Tourism enterprises sometimes tend to project themselves as ecotourism providers, but indulge in 'environmental opportunism', 'greenwashing' and 'eco-exploitation' (Wood, 2002; Medina, 2005; Donohoe and Needham, 2006; Honey, 2008). In this regard, Donohoe and Needham (2008) identify a continuum that exists at the operational level which can be used to distinguish authentic ecotourism with pseudo ecotourism. The latter is more prominent in India. Essentially, across many protected areas, most principles of ecotourism are not imbibed (Banerjee, 2010), and what remains is 'greenwashing'. It includes unregulated development of relatively undisturbed areas, appropriation of ancestral lands, or just applying traditional tourism development models under the guise of ecotourism, misuse of eco-labels and a superficial image of environmental consciousness. Though several luxury resorts established adjacent lands to promote themselves as 'eco-lodges' with the adoption of recycling or rainwater harvesting, such lopsided marketing strategies are often adopted only to maximize profits (Donohoe \& Needham, 2008; Self and BellHaynes, 2010). The same is also found commonly outside the protected areas in India. Sadly, several State tourism development corporations too have joined the bandwagon of pseudo ecotourism by ignoring the very definition of ecotourism and have started promoting nature/culture based mass tourism without integrating environmental and socio-economic sustainability into their policies.

There are two reasons why such pseudo ecotourism tactics continue to thrive in India. First, there is absence of a stringent certification policy or a code of conduct for tourism facilities around protected areas which could monitor compliance. Second, consumers' travel choices are based on popularity, price mechanisms, access, and provision of facilities. Unfortunately, they are largely disconnected from local conservation and livelihood realities and are unaware of the restrictions imposed on locals that live in and adjacent to protected areas. The existing model of tourism also questions the long-term sustainability in these regions (Narain et al., 2005; Mathur et al., 2011). The negative impacts of pseudo ecotourism or mass tourism result in environmental degradation that could ultimately lead to loss of the aesthetic and recreational value of protected areas. Consequently, this affects financial return on tourism infrastructure investments (Puri, Karanth and Thapa, 2018). In this context, there is an urgent need for an institutional and policy-level impetus towards ecotourism in terms of a formalized framework, skill development and monetary support (Sekhar, 2003). Apart from institutionalization of regulations for private businesses to adhere to standards, and education of visitors about sustainable travel choices, there is an urgent need for an integrated transdisciplinary action research and outreach. This would also stimulate a rigorous discourse on sustainability practices as well as encourage appropriate policy interventions across the related sectors - forests, agriculture, fisheries, water, energy, pollution control, waste management (Poyyamoli, 2007, 2008 and 2011; Puri, Karanth and Thapa, 2018). 
In spite of the unlimited potential, there are very few examples from India where revenues earned are ideally routed back to conservation and/or for the benefit of rural poor through either community based or community run ecotourism enterprises or in partnerships with private companies $^{2}$ (Puri , Karanth and Thapa, 2018). Notable among them are: Periyar Tiger Reserve, Thekkady (community based ecotourism in partnership with forest department, Kerala); Kumbalangi (a designated community based ecotourism village near Kochi, Kerela); Kumaon Maati outside Corbett National Park (community based ecotourism in partnership with forest department); Gorukana (community based eco-wellness resort at Biligirirangan Hills in Karnataka); Snow Leopard Conservancy (India Trust managed and community based ecotourism in Ladakh); Spiti Ecosphere (NGO managed and community based ecotourism in Himachal Pradesh); Green People (NGO managed and community based ecotourism at the Goat village near Nag Tibba in Mussoorie, Uttarakhand); Mountain Shepherds (community owned and operated ecotourism in Nanda Devi, Garhwal region of Uttarakhand); Himalayan Ark (a privatecommunity partnership based homestays in the Kumaon region of Uttarakhand); Kipepeo (an organisation that partners with local homestays in the Northeastern states of India); Shaam-eSarhad Village Resort in Hodka village, Dangs district, Gujarat); Mawlynnong Village, Mawphlang Sacred Forest, East Khasi Hills (community-based ecotourism in Meghalaya); Manas Maozigendri Ecotourism Society (community owned and operated ecotourism near Manas National Park, Assam); Tipam and Namphake villages (community run ecotourism camp in Assam); Thembang, Nampong villages (community based ecotourism in Arunachal Pradesh); Dzongu Ecotourism Zone, Greater Rangit Valley, Yuksam (managed by the Sikkim forest department with community involvement/participation); Desia Ecotourism company in scenic Koraput Valley and Mangalajodi Ecotourism Trust on the banks of Chilika Lake, Odisha; Khonoma and Dzuleke (community run village homestays in Nagaland).

\section{Ecotourism Policy Guidelines for India: A critical appraisal}

Ministry of Tourism, Govt of India constituted a committee for preparing basic papers on ecotourism policy for which a workshop was held on $26^{\text {th }}$ June 1997. The final draft was approved by the State Ministers for Tourism in a conference held on $27^{\text {th }}$ June 1997, and was released in 1998 (Ministry of Tourism, Govt of India, 1998). Major sources for the ecotourism policy were derived from the guidelines made for the development of national parks (NPs) and protected areas (PAs) for tourism by World Tourism Organization (WTO), Code for Environmentally Responsible Tourism by Pacific Asia Travel Association (PATA), the World Travel \& Tourism Council (WTTC), the Himalayan Tourism Advisory Board and Ecotourism Society. The policy document comprises four chapters: ecotourism definition, ecotourism resources of India, policy and planning, and operational guidelines.

The following is a critical review of the lacuna/gaps in the policy guidelines:

- The very definition itself is erroneous and misleading by being silent on two vital ingredients of ecotourism:

- integration of conservation and sustainable livelihoods and equitable sharing of income by active community participation in ecotourism planning/ implementation;

\footnotetext{
${ }^{2}$ https://the-shooting-star.com/2018/05/14/sustainable-tourism-india/
} 
- Creation of much needed awareness towards the conservation of heritage, natural/cultural assets by participatory, interactive, interpretative and educational experiences.

- Absence of clear guidelines for local institutional set-up, fiscal incentives or community ownership.

- Difficult procedural formalities involving many sanctioning authorities.

- Absence of Specific, Measurable, Attainable, Relevant, Time-bound (SMART) indicators for monitoring, institutional support, incentives and regulations and absence of linkages.

Additionally, the policy fails to acknowledge the nature of the ecological balance. There is a paradigm shift from static balance to the dynamic balance. Under ecotourism resources/products of India, usually other promising ecotourism destination areas are not quoted. For example, islands, rural landscapes with a rich diversity of biota and culture, traditions, lifestyles, renowned historical/religious/architectural monuments, fairs, festivals, folklore, folk dances, variety of traditional arts and crafts, costumes and customs can be highlighted in ecotourism products. Similarly, the heritage resources are completely ignored. Besides, biosphere reserves are not treated appropriately. Thus, there is a lack of clarity even in identifying potential ecotourism resources, let alone the much-needed detailed explanations for including them in the list.

The four cardinal principles of ecotourism policy and planning process are not very clearly stated, leading to ambiguity, for instance:

- What is the 'level' of 'involvement' of local community? Passive vs. active involvement? Community based vs. community run approaches?

- What about the 'resource user conflicts'? For instance, water for irrigation, tourists and industries.

- The third principle - environmental/socio-cultural compatibility of the tourism development (type and scale) - is not adequately supported by the operational guidelines.

- Along with the land use plan, we also need water use plan - integrated ecological land/water use plan. The question of what should be integrated (temporal, spatial, sectoral and other elements, such as ecological /environmental, cultural with socio-economic and political) is not very clear.

Though ecotourism planning framework appears to be adequate, still there are the following lacuna:

- Who will be the ultimate decision makers? It appears that the locals apparently have no say in planning or implementation, whatsoever.

- Though the need for Environmental Impact Assessment (EIA) is mentioned, the equally important social cost-benefit analysis is completely ignored; this is bound to alienate the local communities.

- Ecotourism, by operational principles, is not supposed to cause destruction or serious alteration of critically/ecologically fragile areas, such as wetlands, coral reefs, sea grass beds, rainforests, etc. as these are the very resources on which ecotourism is based. Yet, surprisingly, there is an attempt to dilute the regulations by allowing the same by biased economic cost-benefit analysis. Conventional cost-benefit analysis often ignores the intangible costs/benefits of degradation/conservation and the administration in some states use it as a ploy to promote mass tourism under the guise of ecotourism in ecologically sensitive areas. 
- Though roads and modes of transportation can have much higher environmental impacts on remote locations, scanty attention is paid to them; non-motorized transportation (battery operated solar PV vehicles, cycle, horse/elephant/camel/mule riding) to reduce air/noise pollution must be encouraged in wildlife rich areas. On the contrary, the policy document recommends conventional/modern tourist buses.

The ecotourism operational guidelines also suffer from several drawbacks. Notable among them are:

- The most important cross sectoral impacts of ecotourism and their inseparable linkages to local ecological/environmental, economic cultural and institutional dimensions are nowhere recognized and described.

- There is a dilution of the regulations by allowing the conventional cost-benefit analysis that often ignores intangible costs/benefits of degradation/conservation, and the corrupt bureaucracy use it as a ploy to promote mass tourism under the guise of ecotourism in ecologically sensitive areas.

- The national ecotourism policy has not suggested any quantifiable indicators to monitor activities. The guidelines for monitoring the environmental impacts are woefully inadequate. Socio-cultural impacts so far remain largely neglected. The obvious links between monitoring and regulations or incentives/disincentives are not recognized.

- Ecotourism is supposed to promote non-motorised transportation (battery operated or solar PV vehicles, cycle, horse/elephant/camel/mule riding to reduce air/noise pollution) must be encouraged in wildlife rich areas.

- Though sufficient guidelines are given for avoiding other inorganic chemical pollutants, nothing is mentioned about the use of detergents. Similarly, the policy document is silent on noise pollution.

- Among the key players, the first in the list is government agencies, and the last is the local community. It openly reveals the emphasis on non-participatory, top to bottom, bureaucratic approaches to ecotourism policy and planning. It is assumed that the developers, operators and suppliers are exclusively outsiders, and it suggests that the locals may be 'involved' to the extent possible. This 'involvement' may be interpreted as per the convenience of the ecotourism promoters. Often the locals are employed as menial workers on low wages on a temporary basis.

- The recommended urban planners as ecotourism experts would not have the adequate expertise to deal with wildlife and tribal cultures and artifacts. Surprisingly, nowhere the need for consulting ecologists or environmentalists is emphasized.

- The conflict resolution mechanisms are not sufficiently described.

- Much needed awareness programmes for the locals (to sensitize them for enabling their active participation in restoration/conservation) is nowhere mentioned

- Marketing of ecotourism requires special skills; they are not at all mentioned anywhere.

- The importance of partnerships is nowhere recognized and respected, and, as a result, the policy appears favouring only big corporate players; this is in contradiction to one of the very basic principles of ecotourism - maximizing the benefits to the local people.

- Role of government and other institutions for promoting ecotourism are not specified in the policy. Local benefits of conservation are not given the importance they deserve. Due to the conceptual lack of clarity in defining ecotourism, most of the stakeholders, except forest department, have not taken a proactive role. The result is an apparent conservation bias at the cost of local stakes. Lack of provision for community involvement is a glaring 
example. Even in cases where local community is projected as beneficiaries, benefits mostly confine to employment of a few locals as guides, cooks and sweepers/cleaners. Other forms of benefit sharing are nearly absent in the sector. Even the employment benefit could be higher if capacity building was considered as a prerequisite for assessing the eligibility of locals for different jobs.

- The ecotourism policy document ends with an environmental pledge. This has many redundant points. For instance, the following items may be mentioned: Items 1 and $18-$ use of recycled paper; Items 3, 8 and 17 - alternate sources of fuel; Items 7 and $12-$ planting of saplings.

The following methodologies are very important for evolving environmentally and socioeconomically sustainable ecotourism strategies in any location, but are conspicuously absent from the document: Tourism Carrying Capacity (TCC), Limits of Acceptable Change (LAC), Limits of Acceptable Use (LAU), The Ecotourism Opportunity Spectrum (ECOS), Visitor Impact Management (VIM), Visitor Activity Management Process (VAMP), Ecotourism Certification, and Interpretation.

Finally, it must be mentioned that the National Ecotourism Policy document (Ministry of Tourism, 1998) is not available for download on any government website, whereas the state ecotourism policies are available on websites (for example: Kerala, Karnataka, Gujarat, Himachal Pradesh, Madhya Pradesh, etc.). It makes the policy inaccessible for the researchers/critics to offer viable suggestions for improvement. Only recently the Government of India has released Draft Guidelines for Ecotourism in and around protected areas (Ministry of Environment Forests, Government of India, 2011). National Ecotourism Policy often appears to have conflicts with policies of the tourism sector in India. Tourism policies give priority for infrastructure development (however, turning a Nelson's eye to the waste collection/management services and public toilets) and recommend simplification/dilution of environmental regulations (for example, the draft Coastal Regulation Zone, 2018 rules) to attract large capital inflow. On the contrary, the objective of ecotourism is to minimize new infrastructures and comply with all environmental regulations. Thus, a weak national ecotourism policy is favorable for pseudo ecotourism or mass tourism promoters/providers in sensitive areas.

\section{Ecotourism: The way ahead}

The identifiable gaps between the rhetoric and reality on planning/implementing/ monitoring of ecotourism in India are inseparably interconnected and are the direct consequences of the glaring absence of a commonly accepted definition of ecotourism. National policies and guidelines should be drawn for all the components of ecotourism inculcating the purview of international environmental treaties and related Indian legislations, and incorporating equity and fair trade principles. State wise regulatory institutions and regulations can be based on these guidelines but should reflect grassroots ecological and cultural integrity. While all environmental legislations apply to ecotourism enterprises, the sector cannot sustain without targeted regulations, as it would potentially have significant impacts on environment and social/economic/cultural fabric. Extensive decision making powers of Panchayati Raj Institutions (PRIs) under Schedule XI of Constitution of India could be used to ensure realization of important goals of ecotourism: nature and culture conservation, generating livelihood opportunities, empowerment, and regular monitoring. These constitutional rights need to be taken into account for negotiations under international agreements like General Agreement on Tariffs and Trade (GATT) (ATREE, 2006). 
However, in several states, PRIs are either non-existent or politicized. Existing tourism development fails to actively involve the local self-governance institutions (LSGIs) in its decision making process, planning and implementation. Hence, all the development plans and schemes of all the ministries should factor in a mechanism to get approval of the LSGIs before a tourism or any other project is initiated in the region. Given the strict laws regarding forest and coastal governance in the country, the impacts on local communities assume much greater dimensions (Equations, 2012).

The Green India Mission document envisages tourism as offering an alternative livelihood to communities dependent on natural resources in rural, urban and coastal areas. Though the Ministry of Environment, Forests and Climate Change (MoEFCC) has stressed the importance of improving the quality of forest cover and restoration of ecosystems in general, it remains silent on the most serious problems in and around protected areas - deforestation by excessive mining, indiscriminate industrialization, mega infrastructure projects and the active promotion of wildlife tourism under the guise of ecotourism. Today, community-based or community-driven tourism initiatives are still playing a marginal role and do not receive the impetus they deserve from the government through specific schemes and incentives/disincentives. In the absence of such level playing field, local poor communities will not be able to compete with big operators with the capacity to acquire larger tracts of land and convert them into private forests and beaches, which are then promoted as tourism products. Mere schemes will not be able to ensure that tourism is community-driven. What is needed is a paradigm shift in the way ecotourism is envisaged where communities are central to the venture, and not merely the profits of large tour operators. Furthermore, starting a tourism enterprise might not even be in the interests of the community and the state would need to recognise and respect such values. The (Draft) Guidelines for Ecotourism in and around protected areas issued by the Ministry of Environment and Forests on June 2, 2011 has laid out a detailed set of framework guidelines on the selection, planning, development, implementation and monitoring of ecotourism in India. Given that India's wildlife landscapes are diverse, these guidelines should be necessarily broad with specific 'state ecotourism strategies' to be developed by the concerned state governments, and 'ecotourism plans' to be developed by the concerned authorities mandatorily taking into account these guidelines. The following core values should be central to the guidelines: people-centred, accountable, democratic/ participatory/equitable and nonexploitative, which mandatorily need to be reflected in the 'state ecotourism strategies'. Specific roles and responsibilities should be enumerated for different stakeholders: state governments, protected area management, tourist facilities/tour operators, local communities, temple boards and general public. Types of permissible tourism activities (both in spatial and temporal contexts) should also be listed.

Furthermore, the Scheduled Tribes and Other Traditional Forest Dwellers (Recognition of Forest Rights) Act, 2006 (Government of India, 2006) has not been considered while formulating the draft guidelines. It needs to be ensured that the final guidelines will guarantee that the provisions of this key Act are upheld in the context of the governance and regulation of tourism and rights of forest dwelling communities. It is important to promote ecotourism with the strictest of regulations. While the Ministry of Environment and Forests has issued draft guidelines, it should be ensured that these are finalized after taking into account the responses from the communities and civil society organisations. Finally, there is a dire need for a revised national policy on ecotourism, the responsibility for which should lie jointly with the Ministry of Tourism and the Ministry of Environment, Forests and Climate Change (Equations, 2012). There is still much to be learnt about what works and why for sustainable ecotourism, and how to effectively engage 
communities and manage growth. Critical gaps in knowledge include the long-term effects of various forms of ecotourism on animals in and around protected areas, the net economic/social/cultural impact of ecotourism for communities and how to optimize them, the most effective ways to promote and manage ecotourism, and how best to build the capacity of communities to scale up sustainable ecotourism.

As the existing ecotourism ventures in India vary in nature of origin and scale of operations that range from government ownership to government-private partnership, government-NGO partnership, community owned/run, community owned with government support, etc., the ecotourism policy prescriptions for planning/implementing/monitoring/ regulations would be very different based on the local contexts. The accumulated evidences on the implementation of ecotourism across India strongly recommend the establishment (if it exists, then strengthening) of an independent state level Ecotourism Development Agency with powers to implement unambiguous legal regulations. Ideally, it should ensure the active participation of representatives drawn from all relevant sectors/stakeholders with decision making powers. To start with, they should be provided with training and capacity building inputs on a periodic basis to promote propoor, eco-social enterprises based on well-planned, sustainably-run ecotourism operations. This can facilitate increased investments in protected areas and reserves, conservation of cultural heritage, a reduction in poaching, an increase in the non-consumptive value of wildlife through viewing, and opportunities for rural/coastal/mountain communities to diversify/enhance their livelihoods through tourism-related jobs, revenue-sharing arrangements, and co-management of natural/biocultural heritage resources. All these should be incorporated into the national policy on ecotourism.

Almost all ecotourism destination areas in India (including small islands, coasts, mountains, wetlands, grasslands and other terrestrial and marine ecosystems and habitats) are ecologically/culturally vulnerable, but are of outstanding beauty and rich biological/ cultural/heritage diversity. Hence, only ecotourism can be promoted in such areas (if acceptable to the native communities) by adapting the following appropriate environmental/socio-economic strategies:

- Site improvement is utmost essential. The destination areas should be provided with sustainable sanitation. Ecosan toilet (urine-diverting dry toilet - UDDT), for example, is a closed system that does not need water and, hence, it is ideal where water is scarce or where the water table is high with the risk of groundwater contamination. The toilet is based on the principle of recovery and recycling of nutrients from excreta (both urine and faeces) to create a valuable manure. Other infrastructure may include biogas, solar photovoltaic panels, aerogenerators, etc. Adoption of ecological land/water use planning and ecotechnologies based on 3 Rs (Reduce, Reuse and Recycle) is inevitable option. Other measures may include: developing culturally appropriate facilities (e.g. board walks, trails interpretation centres, etc.), establishment of controls on collection of live specimens, regulation of dumping of untreated mixed solid/liquid wastes, prohibition of mining of beach/river sand, regulated use of boat anchors in coral bottom bays, ban on cutting of trees in camping and trekking areas, restriction on feeding of wild animals, and so on.

- Conserving the vitality and diversity of life by supporting water/nutrient cycles.

- Controlling the human numbers/activities/impacts within the regular absorbing/ carrying capacities and sustainabilities, so that stability, resilience and diversity of the ecosystem are not irreversibly affected.

- Managing visitor behaviour through host control over visitor number, activities and impacts. 
- Reducing poverty by providing alternative livelihoods, promoting equity and improving the quality of life.

- Sustainable use of biodiversity in general and renewable resources and common property resources in particular.

- Changing personal attitudes and practices in tune with cultural diversity and the locally available resources.

- Working towards self-sufficiency to meet the local needs of the communities.

- Integration of conservation and development (policies, legislation, implementation, participation, etc.) based on a gender balanced approach.

- Environmental education/legislation for maintenance of environmental quality/health standards.

- Application of ecological land use planning/zoning (for water also) regulations with appropriate development standards and good site planning principles in tourism areas. Prevention of linear development along road/shorelines (Tanja, 2008; Brown, Sanders, and Reed, 2018).

- Proper maintenance of tourist vehicles for energy conservation and pollution control by using electric cars/vehicles/boats wherever possible or necessary.

- Promotion of tourism activities which use green/sustainable technologies for saving water and energy, preventing pollution, treating waste water, avoiding the production of solid waste and encouraging recycling. Similarly, tourism activities which encourage the use of public and non-motorized transport should be in place.

- Incorporation of interpretation, training/capacity building, outreach programmes and community regulation for all stakeholders; integration of on-site heritage/culture/biodiversity interpretation by elders, healers and locals; putting local limitations on the use/access (both temporal and spatial) - hosts can set limits on access to homelands and sacred sites (spatial limitation); restriction on times for tourist access/use (temporal limitation), permitted tourist activities (activity limitation); and limiting the access to cultural knowledge and rituals (cultural limitation).

- Sharpening political and administrative integrity to solve the sectoral/policy conflicts by optimal trade-offs for enhancing both individual and community benefits at the local/regional levels through more inclusive, participatory governance.

In a nutshell, ecotourism activities should be environmentally, economically, socially and culturally sustainable so that we can achieve the broader sustainable development goals (SDGs) that will ensure greater self-reliance and pro-poor growth. Among the several guidelines available from other destination areas, which can help us revise the national ecotourism policy, are the CESD, Rainforest Alliance and TIES (2006), State of Queensland, (2015), UNEP/Wetlands International/AEWA (2015), the ASEAN Secretariat, Jakarta (2016), ICIMOD and MONREC (2017), Spenceley, Snyman and Eagles (2017), Mancini et al. (2018), Powell, Powell, and Nielandm (2018), Dowling, (undated).

\section{Conclusion}

Based on Ecotourism Policy and Guidelines developed by the Indian Ministry of Tourism in 1998, the Ministry of Environment and Forest in June 2011 called on state governments to frame ecotourism policies to facilitate tourism programmes in protected areas of the country. In addition, the National 12th Five Year Plan (2012-17) targets to increase the net benefit of tourism 
activities for the poor, emphasising that the revenue generated from tourism operations should be utilised for the management of protected areas (Ministry of Environment Forests, Government of India, 2011; NITI Aayog, 2016). Empowering local people aims to encourage the local economy to create a multiplier effect. The role and participation of the local population is the primary target in the economic development of the ecotourism services. The higher the role, the more the local communities receive incentives through enhanced livelihoods and environmental conservation. Towards this end, the revised ecotourism policy should create appropriate inclusive partnerships with local communities by recognizing site specific traditional rights that could assist in adopting successful ecotourism strategies. Enforcing existing laws and regulations related to ecotourism by a system of incentives/disincentives and refining them wherever needed should be emphasized in the forthcoming revised national ecotourism policy.

\section{Acknowledgments}

I am grateful to my former students from the Department of Tourism and Department of Ecology of Pondicherry University and my former PhD scholars who provided me with an opportunity to dive deeper into ecotourism - a fascinating transdisciplinary area. I sincerely acknowledge the support in the form of the infrastructural facilities provided by the Department of Ecology of Pondicherry University.

\section{References}

ATREE (2006). White Paper on Eco-Tourism Policy (Draft). Accessed on 31 July 2018 at http://www.sikkimforest.gov.in/docs/eco_tourism_white_paper.pdf

Banerjee, A. (2010). Tourism in protected areas: Worsening prospects for tigers. Economic and Political Weekly, 6: 27-29.

Brown, G., Sanders, S. and Reed, P. (2018). Using public participatory mapping to inform general land use planning and zoning. Landscape and Urban Planning, 177 (2018): 64-74.

Donohoe, H.M. and Needham, R.D. (2008). Internet-based ecotourism marketing: Evaluating Canadian sensitivity to ecotourism tenets. Journal of Ecotourism, 7(1): 15-43.

Donohoe, H.M., and Needham, R.D. (2006). Ecotourism: The evolving contemporary definition. Journal of Ecotourism, 5(3): 192-210.

Dowling, R.K. (undated). Geotourism - a Principal Driver of Western Australia Tourism, p.16. Accessed on 27 July 2018 at http://www.leisuresolutions.com.au/wpcontent/uploads/2015/02/Small-Geotourism-10-Point-Checklist1.pdf

Equations (2012). Beyond Greening: Reflections on Tourism in the Rio-Process. Positioning paper - Forests, Communities and the Green India Mission: Promises and Failures of Ecotourism. Accessed on 27 July 2018 at www.equitabletourism.org/readfull.php?AID=2705

Government of India (2006). The Scheduled Tribes and Other Traditional Forest Dwellers (Recognition of Forest Rights) Act, 2006 no. 2 of 2007. Accessed on 27 July 2018 at https://indiacode.nic.in/bitstream/123456789/2070/1/200702.pdf

Government of India, Ministry of Environment, Forest and Climate Change (2018). Draft CRZ Notification, 2018, p36. Accessed on 11 Aug 2018 at http://envfor.nic.in/sites/default/files/pressreleases/DRAFT\%20CRZ\%20NOTIFICATION\%2020181.pdf

Healy, R.G. (1994). The "common pool" problem in tourism landscapes. Annals of Tourism Research, 21(3): 596-611. 
Herbig, P. and O'Hara, B. (1997). Ecotourism: a guide for marketers. European Business Review, 97(5): 231-236. DOI: https://doi.org/10.1108/09555349710179843

Honey, M. (2008). Ecotourism and sustainable development: Who owns paradise? Washington, DC: Island Press.

ICIMOD and MONREC (2017). Guidelines for Developing Ecolodges in Myanmar, p26. $\begin{array}{llllll}\text { Aaccessed } & \text { on } & 27 & \text { July } & 2018 & \text { at }\end{array}$ http://lib.icimod.org/record/32856/files/icimodMyanmarEcotourism.pdf

Karanth, K.K., and DeFries, R. (2011). Nature-based tourism in Indian protected areas: New challenges for park management. Conservation Letters, 4(2): 137-149.

Karanth, K.K., Jain, S., and Mariyam, D. (2017). Emerging trends in wildlife and tiger tourism in India. In J.S. Chen and N.K. Prebensen (Eds.), Nature tourism (pp.159-171). New York: Routledge.

Mancini, M.S., Evans, M., Iha, K., Danelutti, C. and Galli, A. (2018). Assessing the Ecological Footprint of Ecotourism Packages: A Methodological Proposition. Resources 2018, 7(2): 38. DOI: http://doi.org/10.3390/resources7020038, accessed online at http://www.mdpi.com/2079-9276/7/2/38/htm

Mathur, V.B., Gopal, R., Yadav, S.P. and Sinha, P.R. (2011). Management effectiveness evaluation (MEE) of tiger reserves in India: Process and outcomes. National Tiger Conservation Authority, Government of India, p. 97. Available online at: http://projecttiger.nic.in/

Medina, L.K. (2005). Ecotourism and certification: Confronting the principles and pragmatics of socially responsible tourism. Journal of Sustainable Tourism, 13(3): 281-295.

Ministry of Environment Forests, Govt of India (2011). Guidelines for Ecotourism in and around protected areas. Available at: http://www.moef.nic.in/downloads/publicinformation/Draft\%20Ecotourism\%20Guidelines\%202\%20June.pdf

Ministry of Tourism, Govt of India (1998). Ecotourism in India - Policy and guidelines. Government of India, New Delhi.

Mishra, S. and Chandel, A. (2016). Ecotourism revisited: Last twenty-five years. Czech Journal of Tourism, 5(2): 135-154. DOI: http://doi.org/10.1515/cjot-2016-0008

Mittermeier, R.A., Gil, P.R. and Mittermeier, C.G. (1997). Megadiversity: Earth's biologically wealthiestnations. Washington, DC: Conservation International.

Mittermeier, R.A., Turner, W.R., Larsen, F.W., Brooks, T.M. and Gascon, C. (2011). Global biodiversityconservation: The critical role of hotspots. In F. Zachos and J. Habel (Eds.), Biodiversity hotspots (pp. 3-22). Heidelberg: Springer

Moore, S.A. and Rodger, K. (2010). Wildlife tourism as a common pool resource issue: enabling conditions for sustainability governance. Journal of Sustainable Tourism, 18(7): 831-844.

Narain, S., Panwar, H.S., Gadgil, M., Thapar, V. and Singh, S. (2005). Joining the dots: The report of the tiger task force. Project Tiger Directorate, Union Ministry of Environment, Government of India, New Delhi.

NITI Aayog (2016). Appraisal document of twelfth five year plan - 2012-17. Accessed on 27 July 2018 at http://niti.gov.in/writereaddata/files/document_publication/Appraisal\%20Document\%20Fiv e\%20Year\%20Plan\%202012\%20-\%2017-Final\%20\%281\%29.pdf

Powell, L.A., Powell, K., and Nielandm, K. (2018) Guidelines for Ecotourism Operations in the Great Plains Papers in Natural Resources, 699, p.7. Accessed on 27 July 2018 at https://digitalcommons.unl.edu/natrespapers/699

Poyyamoli, G. (2007). Community Based Eco Tourism as connecting thread for ensuring environmental, cultural, economic and social sustainability in India. International Journal 
of Environmental, Cultural, Economic and Social Sustainability, 3(4): 191-198.

Poyyamoli, G. (2008). Eco-cultural tourism for Biodiversity conservation and sustainable development of remote Ecosystems, International Journal of Hospitality and Tourism Systems, 2(1): 79-104.

Poyyamoli, G. (2011). Community Based Eco Cultural Heritage Tourism for Sustainable Development in the Asian Region: A Conceptual Framework. International Journal of Social Ecology and Sustainable Development (IJSESD), 2(2): 66-80.

Puri, M., Karanth, K.K. and Thapa, B. (2018). Trends and pathways for ecotourism research in India. Journal of Ecotourism, May (2018). DOI: 10.1080/14724049.2018.1474885

Sekhar, N.U. (2003). Local people's attitudes towards conservation and wildlife tourism around Sariska Tiger Reserve, India. Journal of Environmental Management, 69(4): 339-347.

Self, R.M., Self, D.R. and Bell-Haynes, J. (2010). Marketing tourism in the Galapagos Islands: Ecotourism or greenwashing? International Business \& Economics Research Journal, 9(6): 111-125.

Spenceley, A., Snyman, S. and Eagles, P. (2017). Guidelines for tourism partnerships and concessions for protected areas: Generating sustainable revenues for conservation and development. Report to the Secretariat of the Convention on Biological Diversity and IUCN, p.59. Accessed on 27th July 2018 at https://www.cbd.int/tourism/doc/tourismpartnerships-protected-areas-web.pdf

State of Queensland (2015). Best Practice Ecotourism Development Guidelines, p.37. Accessed on 27 July 2018 at https://www.ecotourism.org.au/assets/Resources-Hub-EcotourismPlans/Best-Practice-Ecotourism -Development-Guidelines-2015.pdf

Tanja, L. (2008). The development of specific locations into tourist attractions: cases from Northern Europe. Fennia, 186(1): 15-29.

The ASEAN Secretariat, Jakarta (2016a). ASEAN Clean Tourist City Standard, p.52. Accessed on 27 July 2018 at http://asean.org/storage/2012/05/ASEAN-Clean-Tourist-City-Standardrev.pdf

The ASEAN Secretariat, Jakarta (2016b). ASEAN community based tourism standard, p.254. Accessed on 27 July 2018 at http://www.asean.org/storage/2012/05/ASEAN-CommunityBased-Tourism-Standard.pdf

UNEP/Wetlands International/AEWA (2015). AEWA Conservation Guidelines No. 7 Guidelines on the development of ecotourism at wetlands, Technical series no. 22, p39. Accessed on 27 July 2018 at $\underline{\text { https://www.informea.org/sites/default/files/imported- }}$ documents/cg_7new_0.pdf

Vattakaven, T., George, R., Balasubramanian, D., Réjou-Méchain, M., Muthusankar, G., Ramesh, B. and Prabhakar, R. (2016). India biodiversity portal: An integrated, interactive and participatory biodiversity informatics platform. Biodiversity Data Journal, 4, e10279. Doi:10.3897/BDJ.4.e10279

Weaver, D.B. (2001). Ecotourism as Mass Tourism: Contradiction or Reality? Cornell Hotel and Restaurant Administration Quarterly, 42 (2): 104-112

Wood, M. (2002). Ecotourism: Principles, practices and policies for sustainability. UNEP, Division of Technology, Industry, and Economics. Available at http://www.unep.fr/scp/publications/details.asp?id=WEB/0137/PA

\section{Notes}

http://www.grassroutes.co.in/current-trips

http://thegreenerpastures.com/community-eco-tourism-projects-northeast-india

G. Poyyamoli 
https://www.wttc.org/-/media/files/reports/economic-impact-research/documents-2018/globaleconomic-impact-and-issues-2018-eng.pdf https://the-shooting-star.com/2018/05/14/sustainable-tourism-india/ 